INSIGHTS INTO REGIONAL DEVELOPMENT

ISSN 2669-0195 (online) http://jssidoi.org/IRD/

2021 Volume 3 Number 3 (September)

http://doi.org/10.9770/IRD.2021.3.3(3)

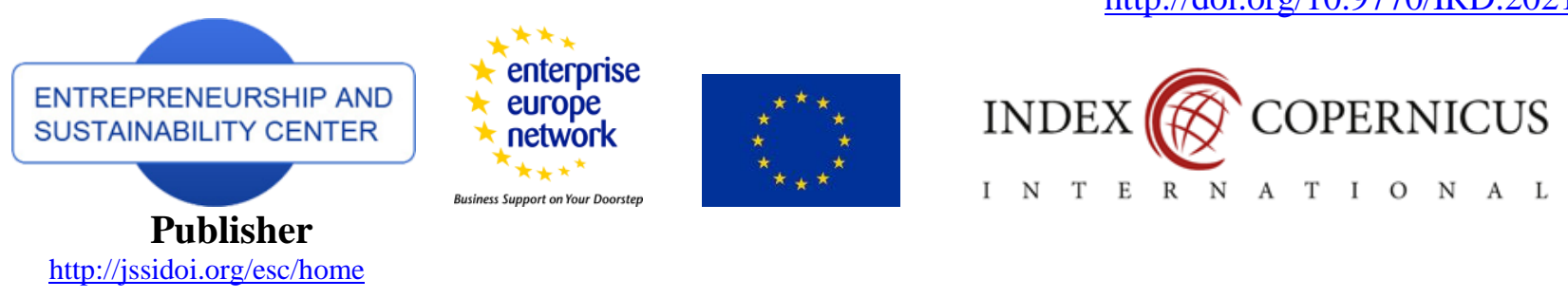

\title{
BUSINESS ENVIRONMENT ANALYSIS BASED ON THE DOING BUSINESS: CASE STUDY SLOVAKIA*
}

\author{
Michal Fabuš ${ }^{1}$, Tomáš Dudáš ${ }^{2}$, Eva Cihelková ${ }^{3}$ \\ ${ }^{1}$ School of Economics and Management in Public Administration, Furdekova ul. 16, 85104 Bratislava 5, Slovak Republic \\ ${ }^{2,3}$ Faculty of Economics and Business, Pan-European University, Tematínska 10, 85105 Bratislava, Slovak Republic \\ E-mails: ${ }^{1}$ michal.fabus@vsemvs.sk; ${ }^{2}$ tomas.dudas@paneurouni.com; ${ }^{3}$ eva.cihelkova@paneurouni.com
}

Received 15 March 2021; accepted 8 August 2021; published 30 September 2021

\begin{abstract}
Business activity is logically influenced by a certain environment in which it takes place. We call this the business environment. It consists of conditions in a specific country, respectively. specific location. Today, we can also talk about the global business environment. The business environment consists of all entities in the vicinity of the company, which directly or indirectly affect it and interfere with its activities. Every business or person doing business operates in a specific business environment. The business environment should create the conditions for entrepreneurs to pay them start-ups and existing ones to thrive in business, while being able to offer vacancies. Based on the Doing business indicator in this paper, we analyze the development of the business environment in the Slovak Republic for the period 2009 to 2020. The data were used in an international database available online within the data provided by the World Bank. The aim of this paper is to point out the development and analyze the reasons for development trends in the Slovak Republic.
\end{abstract}

Keywords: business environment; doing business; Slovak Republic

Reference to this paper should be made as follows: Fabuš, M., Dudáš, T., Eva Cihelková, E. 2021. Business environment analysis based on the Doing Business: case study Slovakia. Insights into Regional Development, 3(3), 56-65. http://doi.org/10.9770/IRD.2021.3.3(3)

JEL Classifications: E22, F21, F43

\section{Introduction}

The business environment is an issue that affects every person and their impact it is much more important than it looks on the outside. Nowadays, a quality business is needed environment, which represents a certain basis in the long-term development of business activities. This environment has a direct effect on the sustainable improvement of economic performance as well as the environment population level. The business environment reflects the quality of the conditions under which business entities carry out business activities.

\footnotetext{
* This paper is the output of an international project of the Grant Agency Academia aurea no. GA_10_5 / 2020 entitled "International business environment - a concept determining current changes and megatrends of future development (with emphasis on quantification phenomena and the response of companies)' and IGA no. 1/2020 "International business environment - determinant of current trends" (Funder: VSEMvs IGA VSEMvs, i.e. School of Economics and Management in Public Administration, Slovak Republic)
} 


\section{INSIGHTS INTO REGIONAL DEVELOPMENT}

ISSN 2669-0195 (online) http://jssidoi.org/jesi/

2021 Volume 3 Number 3 (September)

http://doi.org/10.9770/IRD.2021.3.3(3)

The business environment consists of an extensive system of certain rules, factors, and conditions, which together influence and condition the very establishment and functioning of enterprises in the economy.

The business environment is the environment in which companies carry out their activities. It consists of several conditions for doing business in the field of legislation, in the field of institutional infrastructure and in the field of functioning of markets. If we want to concretize a closer business environment, it is necessary to state that it is made up of legislative bodies and ministries, state administration bodies, state-established or state-supported institutions and agencies, courts, public self-government bodies, educational establishments of all types, research and development workplaces, entities operating in the field of finance, such as banks, insurance companies, institutions capital market, leasing companies, business self-government (unions, associations, chambers, associations, etc.) and advisory, intermediary and other organizations. Thus, not to mention the whole of market participants, which are potential competitors and potential cooperating entities.

In a broader sense of the business environment, there are factors at the macro level that exist regardless of the existence and position of individual business entities. These economic factors are classified as a result of the nature and orientation of the country's economy, while economic also affects changes in material, energy, monetary, investment and information conditions.

The business environment needs to be maintained in quality for business to be sufficiently developed in each of the economies. Business environments are therefore mapped and analyzed thanks to available statistical data, which are obtained at the global level. Through analyzes, areas in which the business environment or competitiveness lags are identified in individual economies. It is a comparison between countries and so the results of the countries are reflected either in relation to economically close neighboring countries, or within Europe, for example, it is a comparison of countries with the European average.

\section{Theoretical background}

During the life cycle of a business, the company and its activities are affected by the effects of the business environment. The business environment is therefore limited to a set of external and internal factors that affect, directly or indirectly affect the company. The individual factors can interact with each other and be connected in a way that will subsequently affect the business. It is also possible to look at the business environment as a specific group of factors that entrepreneurs consider important and these factors are quantifiable, ie they can be compared between the economies of countries, both globally and regionally.

Canadian International Development Agency characterises business environment as the existence of a competitive domestic market linked with the global economy, managed by a well-defined legal and regulatory environment and equipped with a strong and growing human capital base and sufficiently developed infrastructure. The issue of determinants of business environment is up-to-date and dealt with in several publications by both Slovak and foreign authors. The significance of factors affecting business environment is dealt with by e.g. Guay (2014), Hallberg (2006), Hamilton and Webster (2015), Harrison (2014), Wetherly, and Otter (2014), Wagner (2016). Hallberg explains that business rules are laid down by governments through adopted decisions. Positive principles such as transparency, responsibility, encouragement of competition, enforceability of rights and safeguarding of assets should be applied upon the formation, respectively improvement of conditions for business. (Hallberg, 2006). The scope of business extends from individual ownership to an international company. However, several entities (so-called stakeholders) are involved in the business, not only from within the company, but also from the external environment, with which the entrepreneur interacts with each other. 


\section{INSIGHTS INTO REGIONAL DEVELOPMENT}

ISSN 2669-0195 (online) http://jssidoi.org/jesi/

2021 Volume 3 Number 3 (September)

http://doi.org/10.9770/IRD.2021.3.3(3)

Wetherly opines that mutual interaction occurs between business entities and business environment. Businesses are influenced by the environment they operate in as well as they have an influence on their environment. It is in the interest of businesses to participate in the formation of business environment to enforce their own measures with resulting benefits for them (Wetherly and Otter, 2014). According to Harrison, a particular business environment can be characterised based on identifying and detailing its key factors and perspectives. In some cases, individual perspectives are denoted as environments themselves regarding the fact that they frame business environment (Harrison, 2014).

Individuals and organizations need to be well acquainted with the global as well as the local business environment to be able to manage and trade across cultures, trade across national and legal borders, and plan for an increasingly competitive and unpredictable future (Krugman and Obstfeld, 2015; Stokes and Wilson 2016). The business environment is changing due to the irreversible forces of globalization. These changes are many, but include uneven developments around the world, the increased impact of transforming economies, the continuing impact of information and communication technologies, and growing pressure on the natural environment (Peng and Meyer 2016). An important consequence of these changes is that the individuals with whom future managers will respond will be influenced and derive their identity from different contexts compared to the past. In response to this changing environment, organizations and individual managers will need to adapt (Rugman and Collinson 2012). Discontinuous changes in the legal, political, economic, and cultural aspects of the international business environment will continue to emphasize the need to understand its intercultural aspects in the foreseeable future (Thomas and Peterson, 2018)

Business, respectively business environment are also dealt with in Slovac publications by authors such as Tancosova (2013, 2014), Hudakova (2010), Majtán et al. (2012), Fabus (2018) who develops knowledge on the personal qualities of an entrepreneur, which are based on their professional, practical as well as business experience (Majtán et al., 2012), Martinovičová et al. (2014), who partially focuses on the issues of business risk (Martinovičová et al., 2014), Juríčková et al. (2006), who characterises three levels of business environment and their analyses (Juríčková et al., 2006). New trends in business and startup communities' amoung young people are focusing on creativity, new ideas and inovations (Hudakova, Papula, 2016).

Numerous the newest papers wordwide continue to be devoted devoted to various facets of business environment. E.g. Moller et al. (2020) tackle networks, ecosystems, fields and market systems, asking what sense of the business environment is. Gogokhia and Berulava (2021) focus on business environment reforms, innovation and firm productivity in transition economies. Lux et al. (2020) analyze entrepreneurs in their entrepreneurial ecosystems. Penttila et al. (2020) writes about managerial sensemaking in a transforming business ecosystem. Ibidunni et al. (2021) emphersize the contingent role of business environment in building entrepreneurial competencies for good performance of informal SMEs. Jimenez et al. (2021) analyze codes of conduct in the digital environment. Osiyevskyy et al. (2020) focus on firm performance in crisis environment. Kogut et al. (2021) compares cross-country entrepreneurial environment attractiveness. Estevao et al. (2020) underline the relationship between The Doing Business ranking and the GDP growth. This particular direction is further elaborated in this paper with the particular focus on Slovakia kept.

\section{Research objective and methodology}

The Doing Business project was officially created and launched in 2002 with a focus on small and medium-sized enterprises. It has gradually gained in size and value by acquiring and analyzing data in a comprehensive and quantitative form by comparing business regulatory environments across time and economies in a study. The first Doing Business study was published in 2003. The Doing Business study is considered a very valuable tool for 
assessing business environments, used by governments, for example, to design sound regulatory policies. It is important to note that this is not an investment guide, but a tool to simplify business. Doing Business is the World Bank project and is published annually. This project examines the rules governing businesses that improve or worsen business in the countries surveyed, on the basis of these forms of quantitative indicators and, accordingly, compares and ranks the 190 countries of the world (2020). It offers information for those who want to start or expand their business.

The World Bank gathers information on ten areas of business and data obtained from each area-sub indicator is summarized into indicators. Countries are also ranked by individual indicators and the summary indicator, according to ease of doing business, based on which are arranged in the world rankings.

Based on the Doing business indicator in this paper, we analyze the development of the business environment in the Slovak Republic for the period 2009 to 2020. The data were used in an international database available online within the data provided by the World Bank. The aim of this paper is to point out the development and analyze the reasons for development trends in the Slovak Republic.

\section{Results and discussion}

We will primarily reflect the current state of the business environment in Slovakia on a scale according to the global Doing Business study focused primarily on the business environment of small and medium-sized enterprises. The Doing Business 2020 study belongs to the analysis of 190 economies of the world for the period May 2018 - May 2019. The results of the 2020 study, as well as the compiled ranking of economies, are valid as of May 1, 2019. New Zealand's economy ranked first in the rankings, with an overall Doing Business score of 86.8 points. Somalia took the last $190^{\text {th }}$ place with a score of 20.0 points.

If we look directly at Slovakia, it ranked $45^{\text {th }}$ in the Doing Business 2020 rankings, while it has fallen by 3 places since 2019. See below the figure the gradual development of the Slovak economy in the Doing Business evaluations.

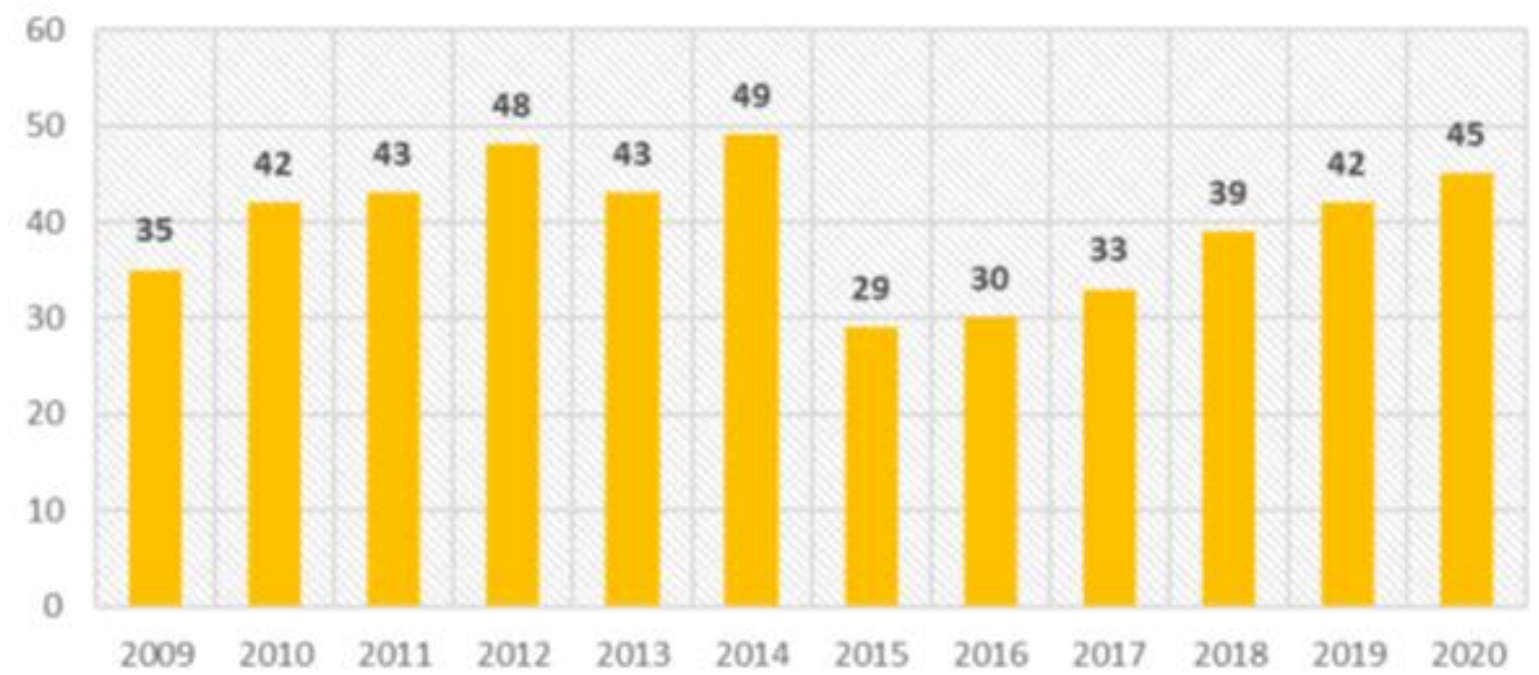

Figure 1. Ranking of the Slovak Republic according Doing business 2009-2020

Source: WORLD BANK GROUP. 2019. Doing Business 2020. [online]. 


\section{INSIGHTS INTO REGIONAL DEVELOPMENT}

ISSN 2669-0195 (online) http://jssidoi.org/jesi/

2021 Volume 3 Number 3 (September)

http://doi.org/10.9770/IRD.2021.3.3(3)

The figure shows the position of the Slovak Republic in the Doing Business rankings for specific years. This means that, as we have already mentioned, in 2020 Slovakia was in $45^{\text {th }}$ place in the ranking. The lower the number, the better the business environment. Slovakia performed best in the Doing Business 2015 study, where it was ranked $29^{\text {th }}$. Since then, our rating has continued to move up. This can be caused either by the stagnation of the Slovak business environment or by faster improvement of other countries compared to ours.

In Doing Business 2020, Slovakia has a total Doing Business score of 75.6 points. Slovakia has made several changes in the last year, which were pointed out in Doing Business 2020:

- One of the changes concerns employee regulations. In this area, Slovakia has increased bonuses for employees for their work at night and on non-working days.

- The study also points to changes in the public procurement process. Public procurement is the government purchase of goods and services from private enterprises for the state. It can be, for example, the use of these goods and services in infrastructure, transport, education, and the like. Effective regulations are important in this process to avoid significant losses of public funds. Slovakia, together with Italy, has shown greater responsibility for lower road construction costs, as well as responsibility for transparency in advertising and tenders.

The Doing Business Summary of the individual countries and the reforms carried out for the period May 2018 May 2019 pulls out such reforms that have either made it easier or more difficult to do business in a given country. They are divided under the individual methodologies examined in Doing Business. In this sense, Slovakia is depicted in two methodologies:

- Start of business - in this methodology, Slovakia implemented a reform that facilitated business activity. This is the abolition of the requirement to obtain and submit information on tax arrears.

- Employment of workers - in the case of the methodology Employment of workers, as mentioned above, the individual scores of economies were not evaluated. Ie. that the study does not indicate whether the change affected the economy in a positive or negative sense. As we have already mentioned in the changes regarding employment, Slovakia has increased employee bonuses for work at night and on nonworking days (weekends and holidays).

Slovakia is visibly introducing changes / regulations to improve the business environment in the country. However, it is still necessary to adjust more dynamically from Slovakia, as in recent periods there has been a decline in the ranks of the Doing Business ranking compared to other world economies.

The Start-up indicator measures the number of procedures, time, costs, and the paid-up minimum capital requirement for the establishment of small and medium-sized enterprises. The indicator Starting a business while growing from $127^{\text {th }}$ to $118^{\text {th }}$ place means an increase in the ranking of evaluated countries by 9 places up. The number of procedures required to start a business decreased from 8 to 7 in 2019. In addition to this reduction, the time required to complete these procedures was reduced from 26.5 days to 21.5 days. According to the revised data, there was no actual deterioration compared to 2018, there was an improvement of 2.78 points. A positive consequence of a slight increase in this indicator is that the cost of setting up a business has decreased, from 1.1\% to $1.0 \%$ of per capita income. There was also a change in the perception of the minimum amount of the deposit for the establishment of a company, where we can talk about a change to $16.4 \%$ of per capita income from the original $17.2 \%$ of per capita income.

The second indicator where the location has decreased is the indicator Obtaining a building permit. This indicator remains one of the areas where there is considerable room for improvement, and in which the Slovak Republic lags far behind in terms of comparison with other indicators. 


\section{INSIGHTS INTO REGIONAL DEVELOPMENT}

ISSN 2669-0195 (online) http://jssidoi.org/jesi/

2021 Volume 3 Number 3 (September)

http://doi.org/10.9770/IRD.2021.3.3(3)

Within the indicator Access to electricity, the Slovak Republic recorded a deterioration and a downward shift in the ranking by 7 places, i.e. from $47^{\text {th }}$ place to $54^{\text {th }}$ place. There has been an increase in costs, but a reduction in the time required to obtain a connection to electricity.

The Property Registration indicator recorded a minimal increase in the score, and there was also an increase in the ranking by 1 place. As part of the DB evaluation, the World Bank states that the Slovak Republic excels in the high quality of real estate and land management, as well as in the low costs of transferring ownership of real estate. This indicator has long been one of the areas in which the Slovak Republic has long been ranked high.

The Credit Acquisition indicator examines two sets of issues - the strength of credit reporting systems and the effectiveness of collateral and bankruptcy legislation in facilitating lending. Scoring of the indicator Borrowing did not change in the last year compared to the previous year. However, due to the improvement of other countries, the Slovak Republic fell by 4 positions in the ranking.

The protection of minority investors measures the strength of the protection of minority shareholders against misuse of company assets by directors for their personal gain, as well as shareholder rights, management guarantees and company transparency requirements that reduce the risk of abuse. Within this indicator, there was a point change of 2.67 upwards, the placement improved by 7 places.

The indicator Tax obligations of companies is the recording of taxes and mandatory contributions that a mediumsized company must pay or withhold in a given year, as well as the administrative burden of paying taxes and contributions and compliance with additional survey procedures (VAT refund and tax audit). The Slovak Republic achieved a deterioration of 0.02 points in this indicator, which means a shift down from $48^{\text {th }}$ place to $55^{\text {th }}$ place.

DB within the indicator Cross-border trade records the time and costs associated with the logistics process of export and import of goods. It measures the time and cost (excluding tariffs) associated with the three sets of procedures - compliance with documents, compliance with borders and domestic transport - in the overall process of exporting or importing goods.

The Slovak Republic recorded an improvement within the indicator Enforceability of Contracts, which was reflected in the ranking. In this indicator, the Slovak Republic achieved an improvement of 1 place, from $47^{\text {th }}$ place to $46^{\text {th }}$ place. This improvement was due to the introduction of electronic communication between the state administration and entrepreneurs, as well as the introduction of electronic means in court proceedings.

The score was reduced within the Insolvency Resolution indicator, where it refers to a reduction in the score by 1.40 points. This deterioration was due to a reduction in the recovery rate. This point shift affected the position, and thus the Slovak Republic is moving from $42^{\text {nd }}$ place to $46^{\text {th }}$ place within this indicator.

Taking a closer look at the overall evaluation of the Slovak Republic within the EU member states, it defended it position in $18^{\text {th }}$ place. Among the leading countries in the ranking within the EU is Denmark, which, as in the previous year, is in $3^{\text {rd }}$ place. The last places this year, as well as the previous year, were occupied by Greece and Malta. Most EU countries saw a decline compared to last year. Austria and Germany recorded a decrease of 4 places, Ireland a decrease of 6 places. Belgium and the Netherlands, on the other hand, saw a slight increase compared to the previous year. 


\section{Conclusions}

As already mentioned, Slovakia's position in the monitored periods had an increasing but also declining tendency. Each year, the World Bank examines business environment regulations and laws affecting business in 190 countries. In the final evaluation, which he will finally issue, there are 10 indicators of partial evaluations. The Ministry of Economy of the Slovak Republic is trying to create a better business environment for Slovakia, but the location in the DB signals that this effort is not sufficient. Out of 190 countries, Slovakia ranked $45^{\text {th }}$. Which does mean significant decline and fall in the DB ranking. This year's score of the Slovak Republic is 75.6 points. In the scoring, this means a slight improvement of 0.2 points compared to last year. Compared to last year's evaluation, this represents a decrease in the overall ranking of evaluated countries by 3 places.

Other problematic aspects include the indicator of obtaining a building permit, which is an area in which we can improve. Slovakia lags far behind in this area. Compared to last year, the improvement is only 0.1 point. (59.4). Ministry transport and construction of the Slovak Republic must adopt comprehensive reforms in this sector. In the business environment of the Slovak Republic, packages were also mentioned - (anti-bureaucratic package), which was imposed by the Slovak government on the Minister of Transport and Construction. This package contained 6 tasks focused on the area of construction proceedings, including the preparation of a new construction law. This law is key to improving the indicator. Another category in the ranking is Electricity generation. The Slovak Republic recorded an almost imperceptible improvement in this area 38 with last year's score of 0.1 points. (83.3). Unfortunately, we were ranked $54^{\text {th }}$. There was also a reduction in time and an increase in the cost of obtaining electricity.

Within the indicator Starting business, there was the biggest shift compared to last year. We rank $118^{\text {th }}$ in the ranking. In the point evaluation, Slovakia improved by 2.9 points. (84.8). Individual indicators change from year to year and adjust our position in DB rankings. According to the World Bank, the Slovak Republic excels in low costs for the transfer of ownership of real estate and high quality of land and real estate management. This is the only indicator in which the Slovak Republic has been ranked high for long time. The largest positive shift was in the indicator of Compliance with Contracts, where the Slovak Republic recorded significant improvement. Compared to $84^{\text {th }}$ place, we moved to $46^{\text {th }}$ place due to the electronic communication of entrepreneurs with the state administration and the introduction of electronic means in court proceedings. Finally, it is necessary to mention the decrease that occurred in the last monitored indicator, and that is the Resolution on Bankruptcy by 1.4 points $(65.5)$.

The decline that was recorded in the ranking of the evaluated countries this year must not discourage the Slovak Republic from the goal of building the most favorable business environment for entrepreneurs. It should be noted that the government is striving to improve our position in the international rankings, but the primary goal remains to improve the business environment. 


\section{INSIGHTS INTO REGIONAL DEVELOPMENT}

ISSN 2669-0195 (online) http://jssidoi.org/jesi/

2021 Volume 3 Number 3 (September)

http://doi.org/10.9770/IRD.2021.3.3(3)

\section{References}

Doing Business. (Official website). About us. 2020. Retrieved from http://doingbusiness.org/

Doing Business. (Official website). Doing Business in Slovak Republic. 2020. Retrieved from http://doingbusiness.org/data/exploreeconomies/slovakia/

Doing Business. (Official website). Methodology. 2020. Retrieved from http://doingbusiness.org/methodology

Doing Business. (Official website). Statistical Data. 2020. Retrieved from http://doingbusiness.org

Estevao, J., Lopes, J.D., Penela, D. \& Soares, J.M. 2020. The Doing Business ranking and the GDP. A qualitative study. Journal of Business Research, 115, 435-442 http://doi.org/10.1016/j.jbusres.2019.11.067

Fabus, M. 2018. Business environment analysis based on the Global Competitiveness Index (GCI) and Doing Business (DB): case study Slovakia. Journal of Security and Sustainability Issues, 7(4), 831-839. http://doi.org/10.9770/jssi.2018.7.4(18)

Gogokhia, T. \& Berulava, G. 2021. Business environment reforms, innovation and firm productivity in transition economies. Eurasian Business Review, 11(2), 221-245. http://doi.org/10.1007/s40821-020-00167-5

Guay, T. 2014. The Business Environment of Europe. Cambridge: Cambridge University Press, 2014.

Hallberg, K. 2006. Improving Investment Climates. Washington: The World Bank, 2006.

Hamilton, L. \& Webster, P. 2015. The International Business Environment. The 3rd Edition. Oxford: Oxford University Press.

Harrison, A. 2014. Business Environment in a Global Context. The 2nd Edition. Oxford: Oxford University Press, 2014.

Hudakova, M. \& Papula, J. 2016. Podnikanie a podnikatel'ské myslenie II. Wolters Kluver. Praha. 2016. ISBN 978-80-7478-994-6

Hudakova, M. 2010. Small and Medium Sized Enterprises in Slovakia. 2010. In: The impact of V4 Countries in the European Union on enterprise and regional development. Bratislava: Merkury, pp. 99-104. ISBN 978-80-89458-20-2

Ibidunni, A.S., Ogundana, O.M. \& Okonkwo, A. 2021. Entrepreneurial Competencies and the Performance of Informal SMEs: The Contingent Role of Business Environment. Journal of African Business http://doi.org/10.1080/15228916.2021.1874784 Early Access

Jimenez, D.L., Dittmar, E.C. \& Portillo, J.P.V. 2021. New Directions in Corporate Social Responsibility and Ethics: Codes of Conduct in the Digital Environment. Journal of Business Ethics http://doi.org/10.1007/s10551-021-04753-z Early Access

Juríčková, V. et al. 2006. Podnikatel’ské prostredie a firemné stratégie. [Business environment and corporate strategies] Bratislava: Ekonomický ústav SAV (in Slovak)

Kogut, C.S., da Fonseca, L.N.M., da Silva, J.F. 2021. Entrepreneurial environment attractiveness: a cross-country longitudinal cluster analysis. Competitiveness Review http://doi.org/10.1108/CR-06-2020-0081 Early Access

Krugman, P. R., Obstfeld, M. 2015. International Economics: Theory and Policy. 10. Ed. Harlow: Pearson Education Limited, 785p. ISBN 978-1-292-01955-0.

Lux, A.A., Macau, F.R. \& Brown, K.A. 2020. Putting the entrepreneur back into entrepreneurial ecosystems. International Journal Of Entrepreneurial Behavior \& Research, 26(5), 1011-1041 http://doi.org/10.1108/IJEBR-01-2020-0031

Majtán, Š. et al. 2012. Podnikové hospodárstvo. [Business Economy] The 2nd Edition. Bratislava: Sprint 2, 2012 (in Slovak)

Martinovičová, D. et al. 2014. Úvod do podnikové ekonomiky. [Introduction to the Business Economy] Praha: Grada, (in Slovak)

Moller, K., Nenonen, S. \& Storbacka, K. 2020. Networks, ecosystems, fields, market systems? Making sense of the business environment. Industrial Marketing Management, 90, 380-399. http://doi.org/10.1016/j.indmarman.2020.07.013

Osiyevskyy, O., Shirokova, G. \& Ritala, P. 2020. Exploration and exploitation in crisis environment: Implications for level and variability of firm performance. Journal of Business Research, 114, 227-239. http://doi.org/10.1016/j.jbusres.2020.04.015 


\section{INSIGHTS INTO REGIONAL DEVELOPMENT}

ISSN 2669-0195 (online) http://jssidoi.org/jesi/

2021 Volume 3 Number 3 (September)

http://doi.org/10.9770/IRD.2021.3.3(3)

Peng, M. \& Meyer, K. 2016. International Business. 2. Ed. Andover: Cengage Learning EMEA, 2016. p. 606. ISBN 978-1-4737-2264-4.

Penttila, K., Ravald, A., Dahl, J. \& Bjork, P. 2020. Managerial sensemaking in a transforming business ecosystem: Conditioning forces, moderating frames, and strategizing options. Industrial Marketing Management, 91, 209-222. http://doi.org/10.1016/j.indmarman.2020.09.008

Rugman, A.M. \& Collinson, S. 2012. International Business. 6. Ed. Harlow: Pearson Education Limited, 765p. ISBN 978-0-273-76097-9.

Stokes, D. \& Wilson, N. 2016. Small business management and Enteprenourship. 7th edition. Hampshire: Cengage Learning EMEA, 496p. ISBN: 978-14-737-2973-5.

Tancosova, J. 2013. Foreign direct investments and their influence on the economic development of Slovakia. Economic Annals-XXI, 34(1), 31-34. Retrieved from http://soskin.info/ea/2013/3-4/zmist.html

Tancosova, J. 2014. Investment attractiveness of Slovak republic and its determinants. Economic Annals-XXI, 3-4(1), 8-11. Retrieved from http://soskin.info/userfiles/file/2014/3-4 2014/1/Tancosova.pdf

Thomas, D.C. \& Peterson, M.F. 2018. Cross-cultural management. Essential Concepts. Fourth edition. London: SAGE, 313p. ISBN 978-15063-8752-9

Wagner, S.M. 2016. The Business Environment of Europe: Firms, Governments, and Institutions. Academy of management learning \& education, 16(1), 169-171. https://doi.org/10.5465/amle.2017.0053

Wetherly, P. \& Otter, D. 2014. The Business Environment. The 3rd Edition. Oxford: Oxford University Press.

\section{Acknowledgements}

This paper is the output of an international project of the Grant Agency Academia aurea no. GA_10_5 / 2020 entitled "International business environment - a concept determining current changes and megatrends of future development (with emphasis on quantification phenomena and the response of companies)' and IGA no. 1/2020 "International business environment - determinant of current trends" (Funder: VSEMvs IGA VSEMvs, i.e. School of Economics and Management in Public Administration) 
INSIGHTS INTO REGIONAL DEVELOPMENT

ISSN 2669-0195 (online) http://jssidoi.org/jesi/

2021 Volume 3 Number 3 (September)

http://doi.org/10.9770/IRD.2021.3.3(3)

\section{Acknowledgement}

This paper is the output of an international project of the Grant Agency Academia aurea no. GA_10_5 / 2020 entitled "International business environment - a concept determining current changes and megatrends of future development (with emphasis on quantification phenomena and the response of companies)' and IGA no. 1/2020 "International business environment - determinant of current trends" (Funder: VSEMvs IGA VSEMvs, i.e. School of Economics and Management in Public Administration, Slovak Republic)

assoc. prof. Ing. Michal FABUS PhD. in Management, obtained at University in Presov; PhD. in International Economics Relations, obtained at University of Economics in Bratislava, Vice-rector for Foreign Affairs, Head of Department of Economics and Finance, School of Economics and Management in Public Administration in Bratislava (VSEMvs), Slovakia.

ORCID ID: orcid.org/0000-0002-3792-179X

assoc. prof. Ing. Tomas DUDAS, PhD. in International business, obtained at Pan-European University in Bratislava, Dean of Faculty of Economics and Business, academic researcher, Faculty of Economics and Business, Pan-European University in Bratislava (PEVŠ), Slovakia.

ORCID ID: orcid.org/ 0000-0001-8931-8987

prof. Ing. Eva CIHELKOVÁ, CSc. in World Economics, obtained at University of Economics, Prague, guarantor of study programs, academic researcher, Faculty of Economics and Business, Pan-European University in Bratislava (PEVŠ), Slovakia.

ORCID ID: orcid.org/0000-0002-7428-1584

Make your research more visible, join the Twitter account of INSIGHTS INTO REGIONAL DEVELOPMENT:

@ IntoInsights

Copyright (C) 2021 by author(s) and VsI Entrepreneurship and Sustainability Center

This work is licensed under the Creative Commons Attribution International License (CC BY).

http://creativecommons.org/licenses/by/4.0/

c) (†) Open Access 